
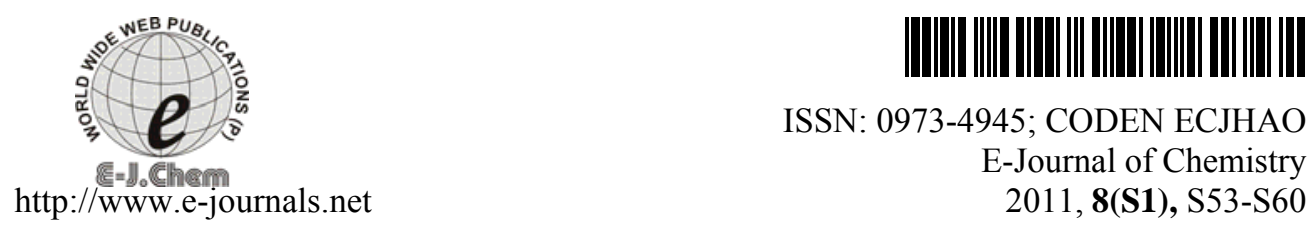

ISSN: 0973-4945; CODEN ECJHAO

E-Journal of Chemistry

2011, 8(S1), S53-S60

\title{
Mitigation of Mild Steel Corrosion in Acidic Solution Using Inhibitor
}

\author{
M.VISHNUDEVAN \\ Department of Chemistry \\ Karunya University Coimbatore - 641114, Tamilnadu, India \\ visdevan@karunya.edu
}

Received 9 February 2011; Accepted 13 April 2011

\begin{abstract}
The inhibition efficiency of mild steel corrosion in $\mathrm{HCl}$ acidic solution containing various concentrations of mixed inhibitors were evaluated by conducting Tafel polarization and electrochemical impedance studies. The mixed inhibitors used in this present investigation were trisodium citrate and sodium benzoate. In this present investigation $0.01 \mathrm{~N}$ to $0.1 \mathrm{~N}$ concentrations of $\mathrm{HCl}$ was used at $30{ }^{0} \mathrm{C}$. Sodium benzoate present in the mixed inhibitive system enhanced the inhibition efficiency through chemisorptions. The maximum inhibition efficiency ( $95.4 \%$ ) was obtained for the mixed inhibitive system containing $0.05 \mathrm{M}$ citrate and $0.5 \mathrm{M}$ benzoate in $0.1 \mathrm{~N} \mathrm{HCl}$.
\end{abstract}

Keywords: Mild steel, Corrosion, Inhibition efficiency, Adsorption, Impedance, Temkin isotherm

\section{Introduction}

Hydrochloric acid and sulphuric acid are the commonly used pickling acids in steel industries. These acids solutions are widely used for removal of undesirable scales and rust present in steel substrate. Inhibitors are mainly used to control metal dissolution and acid consumption. One of the effective methods to prevent corrosion is the use of organic inhibitors ${ }^{1}$. Organic inhibitors generally have electron-rich groups that interact with the metal surface, forms bond and it prevents corrosion through adsorption type, mainly through chemisorptions. Umoren et $a l^{2}$ have invented the corrosion inhibition of mild steel in $\mathrm{H}_{2} \mathrm{SO}_{4}$ in the presence of gum arabic (GA) (naturally occurring polymer) and polyethylene glycol (PEG) (synthetic polymer). The corrosion resistance performance was assessed by conducting weight loss, hydrogen evolution and thermometric studies at 30-60 ${ }^{\circ} \mathrm{C}$. PEG was found to be a better inhibitor for mild steel corrosion in acidic medium than GA. Mirghasem et $a l^{3}$ introduced the inhibition effect of sodium dodecylbenzenesulphonate (SDBS) and 
hexamethylenetetramine (HA) for mild steel corrosion in sulphuric acid. The inhibition effect was studied by using weight loss, electrochemical impedance and Tafel polarisation measurements. The maximum inhibition efficiency of SDBS is found to be at a concentration of about $250 \mathrm{ppm}$. The adsorption of HA can be rationalised using the Langmuir adsorption isotherm, which clearly fails in the case of SDBS. Quraishi et $a l^{4}$ synthesised a new corrosion inhibitor namely, 4-salicylideneamino-3-hydrazino-5-mercapto-1,2,4-triazole (SAHMT), and tested its influence on corrosion inhibition of oil-well tubular steel $(\mathrm{N}-80)$ and mild steel in $15 \%$ hydrochloric acid $(\mathrm{HCl})$ solution under boiling condition using weight loss method. Potentiodynamic polarization measurements clearly reveal that the investigated inhibitor is of mixed type and it inhibits the corrosion of both the steels by blocking the active site of the metal. The adsorption of the Inhibitor on the metal surface from $15 \% \mathrm{HCl}$ has been found to obey Temkin's adsorption isotherm. Divakara Shetty et $\mathrm{al}^{5}$ studied the inhibiting effect of $N$-(furfuryl)- $N$-phenyl thiourea (FPTU) on the corrosion of mild steel in $0.01 \mathrm{M} \mathrm{HCl}$ solution using potentiodynamic polarization technique. The polarization data have shown that FPTU acts as an efficient anodic inhibitor for mild steel in acid solution. Adsorption of this compound on the mild steel surface was found to obey Temkin's adsorption isotherm. The maximum inhibition efficiency of $93 \%$ has been evidenced at $28{ }^{\circ} \mathrm{C}$ and $50{ }^{\circ} \mathrm{C}$ and inhibition is governed by chemisorption mechanism. Migahed et al investigated the synthesized inhibitor $p$-myristyloxy carbonyl methoxy- $p$-sodium carboxylate-azobenzene. The inhibition efficiency of this inhibitor has been studied by both chemical and electrochemical techniques at $25{ }^{\circ} \mathrm{C}$. A significant decrease in the corrosion rate was observed in presence of the investigated inhibitor. The galvanostatic polarization curves showed that, the inhibitor behaves as mixed type but the cathodic effect is more pronounced. The adsorption of the inhibitor molecules obeyed the Langmuir adsorption isotherm. The inhibition efficiency increased with increasing concentration of the inhibitor. Ramesh et $\mathrm{al}^{7}$ have synthesized the selected triazole derivatives and evaluated as corrosion inhibitors for mild steel in natural aqueous environment by weight loss, potentiodynamic polarisation and ac impedance methods. All the condensed products showed good inhibition efficiency (IE). The effect of changing functional groups of some triazole derivatives on their inhibition efficiency was also reported using weight loss and potentiodynamic technique. 3-Salicylalidene amino-1,2,4-triazole phosphonate (SATP) was found to be the best corrosion inhibitor compare to the other compounds. Quraishi et al ${ }^{8}$ discovered the influence of some organic acid hydrazides, namely salicylic acid hydrazide (SAH), anthranilic acid hydrazide (AAH), benzoic acidhydrazide (BAH) and cinnamic acid hydrazide (CAH) on the corrosion behaviour of mild steel in presence of $1 \mathrm{~N} \mathrm{HCl}$. The adsorption of all the hydrazides on mild steel surface in acid medium obey Temkin's adsorption isotherm. The values of activation energy and free energy of adsorption of all the hydrazides were also calculated and the potentiodynamic polarization studies indicated that all the hydrazides except SAH are mixed inhibitors. Vishnudevan et $\mathrm{al}^{9}$ have studied the inhibition characteristics of $N$-benzyldimethylamine for mild steel corrosion in acidic medium. Elkadi et $\mathrm{al}^{10}$ have investigated the inhibition of mild steel corrosion in acidic media by electrochemical methods using 3,6-bis (2-methoxy phenyl)-1 and 2-dihydro-1,2,4,5-tetrazine inhibitors. These mixed inhibitive systems inhibit the mild steel corrosion through adsorption mechanism and it obeys Langmuir adsorption isotherm. In this present investigation inhibition of mild steel in $\mathrm{HCl}$ solution containing sodium benzoate and tri-sodium citrate as mixed inhibitors were analysed electrochemically.

\section{Experimental}

In this present investigation three electrode cell system was used. Mild steel working electrode of $1 \mathrm{~cm}^{2}$ exposed area was used, the electrode was manually polished well with different grades of emery papers $(0,1,2,3$ and 4$)$ and degreased with acetone, platinum foil of 
$2 \mathrm{~cm}^{2}$ area was used as counter electrode and the calomel electrode was used as reference electrode. The blank acidic solutions used in this study were $0.01 \mathrm{~N}, 0.05 \mathrm{~N}$ and $0.1 \mathrm{~N}$ solutions of $\mathrm{HCl}$. The mixed inhibitors of trisodium citrate and sodium benzoate was used with various concentration. Among this mixer, $0.05 \mathrm{M}$ concentration of tri-sodium citrate was fixed constant through out this study with varying only sodium benzoate concentration of $0.05 \mathrm{M}, 0.1 \mathrm{M}$ and $0.5 \mathrm{M}$. Potentiodynamic polarization and electrochemical impedance spectroscopic tests were carried out using $\mathrm{CH}$ instrument electrochemical workstation of model $\mathrm{CH} 1660 \mathrm{c}$. The details of systems studied and the symbol used in this present investigation is given in the following Table 1 .

Table 1. The details of system studied

\begin{tabular}{|c|c|}
\hline System studied & Symbol used \\
\hline $0.01 \mathrm{~N} \mathrm{HCl}$ & Blank $(0.01 \mathrm{~N} \mathrm{HCl})$ \\
\hline $\begin{array}{l}0.01 \mathrm{~N} \mathrm{HCl}+0.05 \mathrm{M} \text { tri-sodium citrate }+0.05 \mathrm{M} \text { sodium } \\
\text { benzoate }\end{array}$ & Blank $+0.05 \mathrm{M}$ tsc $+0.05 \mathrm{M} \mathrm{sb}$ \\
\hline $\begin{array}{l}0.01 \mathrm{~N} H C l+0.05 \mathrm{M} \text { Tri-sodium citrate }+0.1 \mathrm{M} \text { sodium } \\
\text { benzoate }\end{array}$ & Blank $+0.05 \mathrm{M} \mathrm{tsc}+0.1 \mathrm{M} \mathrm{sb}$ \\
\hline $\begin{array}{l}0.01 \mathrm{~N} \mathrm{HCl}+0.05 \mathrm{M} \text { Tri-sodium citrate }+0.5 \mathrm{M} \text { sodium } \\
\text { benzoate }\end{array}$ & Blank $+0.05 \mathrm{M} \mathrm{tsc}+0.5 \mathrm{M} \mathrm{sb}$ \\
\hline $0.05 \mathrm{~N} \mathrm{HCl}$ & Blank $(0.05 \mathrm{~N} \mathrm{HCl})$ \\
\hline $\begin{array}{l}0.05 \mathrm{~N} \mathrm{HCl}+0.05 \mathrm{M} \text { Tri-sodium citrate }+0.05 \mathrm{M} \text { sodium } \\
\text { benzoate }\end{array}$ & Blank $+0.05 \mathrm{M}$ tsc $+0.05 \mathrm{M} \mathrm{sb}$ \\
\hline $\begin{array}{l}0.05 \mathrm{~N} \mathrm{HCl}+0.05 \mathrm{M} \text { Tri-sodium citrate }+0.1 \mathrm{M} \text { sodium } \\
\text { benzoate }\end{array}$ & Blank $+0.05 \mathrm{M} \mathrm{tsc}+0.1 \mathrm{M} \mathrm{sb}$ \\
\hline $\begin{array}{l}0.05 \mathrm{~N} \mathrm{HCl}+0.05 \mathrm{M} \text { Tri-sodium citrate }+0.5 \mathrm{M} \text { sodium } \\
\text { benzoate }\end{array}$ & Blank $+0.05 \mathrm{M}$ tsc $+0.5 \mathrm{M} \mathrm{sb}$ \\
\hline $0.1 \mathrm{~N} \mathrm{HCl}$ & Blank $(0.1 \mathrm{~N} \mathrm{HCl})$ \\
\hline $\begin{array}{l}0.1 \mathrm{~N} \mathrm{HCl}+0.05 \mathrm{M} \text { Tri-sodium citrate }+0.05 \mathrm{M} \text { sodium } \\
\text { benzoate }\end{array}$ & Blank $+0.05 \mathrm{M}$ tsc $+0.05 \mathrm{M} \mathrm{sb}$ \\
\hline $0.1 \mathrm{~N} \mathrm{HCl}+0.05 \mathrm{M}$ Tri-sodium citrate $+0.1 \mathrm{M}$ sodium benzoate & Blank $+0.05 \mathrm{M} \mathrm{tsc}+0.1 \mathrm{M} \mathrm{sb}$ \\
\hline $0.1 \mathrm{~N} \mathrm{HCl}+0.05 \mathrm{M}$ Tri-sodium citrate $+0.5 \mathrm{M}$ sodium benzoate & Blank $+0.05 \mathrm{M}$ tsc $+0.5 \mathrm{M} \mathrm{sb}$ \\
\hline
\end{tabular}

\section{Potentiodynamic polarization studies}

The potentiodynamic polarization studies were carried out with mild steel strips having an exposed area of $1 \mathrm{~cm}^{2}$. A conventional three electrode cell consisting of mild steel as working electrode, Platinum wire as counter electrode and a Saturated Calomel Electrode (SCE) as reference electrode were used. Potentiodynamic polarization studies were carried out with a shift of $\pm 200 \mathrm{mV}$ vs SCE from rest potential using an $\mathrm{CH}$ analyser and the data was calculated with reference to blank sample. In the case of polarization measurements, the potential sweep rate was maintained at $1 \mathrm{mVs}^{-1}$. The inhibition efficiencies were calculated from corrosion currents.

\section{Electrochemical impedance spectroscopy}

Electrochemical impedance measurements were carried out using an electrochemical system frequency response analyser ( $\mathrm{CH}$ 606). The electrochemical impedance spectra (EIS) were acquired in the frequency range $10 \mathrm{kHz}$ to $10 \mathrm{mHz}$ at the rest potential by applying $5 \mathrm{mV}$ sine wave $\mathrm{AC}$ voltage. The polarization resistance $(\mathrm{Rp})$ and corrosion rate (mmpy) were determined $^{11,12}$ from Nyquist plots for different concentrations of $\mathrm{HCl}$ and in mixed inhibitive system. The inhibition efficiencies were calculated from Rp values and tabulated in Table 3. 


\section{Results and Discussion}

\section{Potentiodynamic polarisation of mild steel in different concentration of $\mathrm{HCl}$}

The Tafel polarisation characteristics of mild steel in $\mathrm{HCl}$ with mixture of trisodium citrate and sodium benzoate were represented in Figures 1 to 3 and the electrochemical kinetics parameters such as corrosion potential $\left(\mathrm{E}_{\text {corr }}\right)$, corrosion current $\left(\mathrm{I}_{\text {corr }}\right)$, Tafel slopes $\left(\beta_{\mathrm{a}}, \beta_{\mathrm{c}}\right)$ were calculated and tabulated in Table 2.

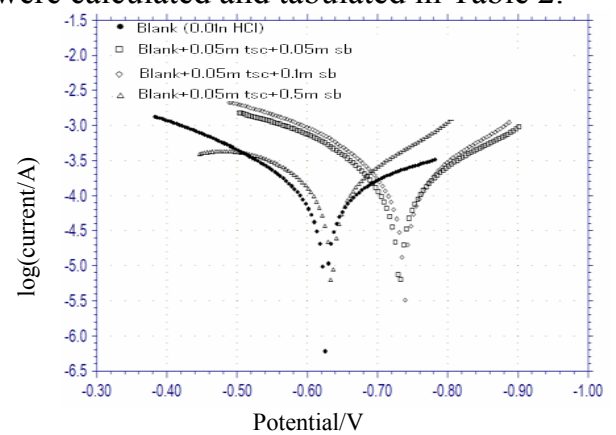

Figure 1. Tafel curves of mild steel in $0.01 \mathrm{~N}$ $\mathrm{HCl}$ in absence and presence of various concentration of citrate and benzoate inhibitors

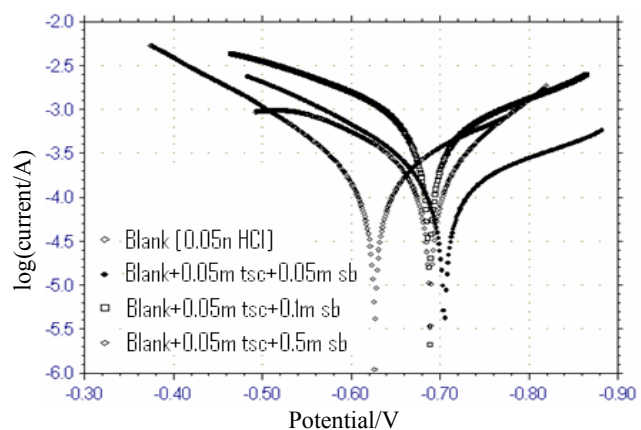

Figure 2. Tafel curves of mild steel in $0.05 \mathrm{~N}$ $\mathrm{HCl}$ in absence and presence of various concentration of citrate and benzoate inhibitors

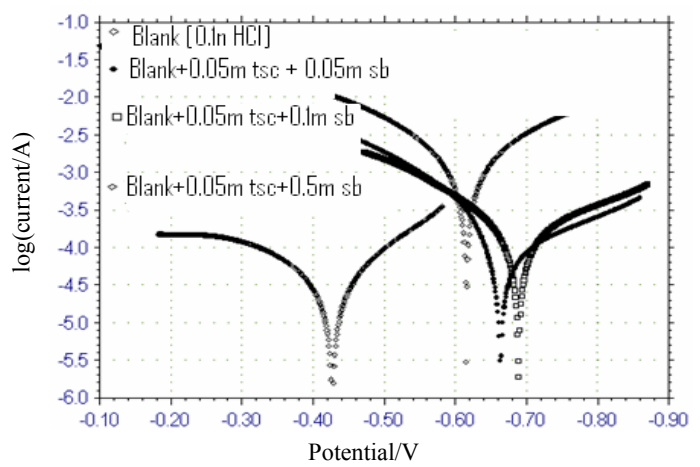

Figure 3. Tafel curves of mild steel in $0.1 \mathrm{~N} \mathrm{HCl}$ in absence and presence of various concentration of citrate and benzoate inhibitors

The corrosion rate (mmpy) of mild steel is measured by using the following equation; Corrosion rate $(\mathrm{mmpy})=3.2 \times \mathrm{I}_{\text {corr }}\left(\mathrm{mA} / \mathrm{cm}^{2}\right) \times$ equivalent weight of iron/density. The corrosion inhibition efficiency was calculated from the following relationship \% Inhibition Efficiency $=\left\{1-\mathrm{I}_{\text {corr }} / \mathrm{I}_{\text {corr }}^{0}\right\} \times 100$.

Where $\mathrm{I}_{\text {corr }}^{0}$ and $\mathrm{I}_{\text {corr }}$ are the uninhibited and inhibited corrosion current densities for mild steel in $\mathrm{HCl}$ and with various concentrations of mixed inhibitive system, viz trisodiumcitrate and sodium benzoate. From the Table 2, it is observed that the corrosion current density $\mathrm{I}_{\text {corr }}$ of mixed inhibitive system (Trisodium citrate and sodium benzoate) decreased considerably with the increase in concentration of inhibitors. From the result, it is observed that the presence of sodium benzoate in the mixed inhibitive system enhanced the corrosion resistance properties through adsorption mechanism, i.e, when the concentration of the inhibitor increases then the surface coverage $(\Theta)$ also increases significantly which is shown in Figure 4 and hence it obeys Temkin adsorption isotherm. The adsorption of both 
citrate and benzoate on the mild steel electrode is confirmed by scanning electron microscopy (SEM) image shown in Figure 5 for blank and mixed inhibitive systems. The maximum inhibition efficiency of $95.4 \%$ was obtained in the case of Blank $+0.05 \mathrm{M}$ Tsc $+0.5 \mathrm{M}$ $\mathrm{sb}$, it is due to the synergistic action of benzoate and citrate over the mild steel surface. Another interesting observation made was when the concentration of the $\mathrm{HCl}$ acid is increases along with the inhibitors concentration of inhibitors, the inhibition efficiency is also correspondingly increases due to the protonated adsorption film formed on the surface of the mild steel.

Table 2. Polarisation parameter for the corrosion of mild steel in different concentration of $\mathrm{HCl}$ and in different concentration of inhibitors

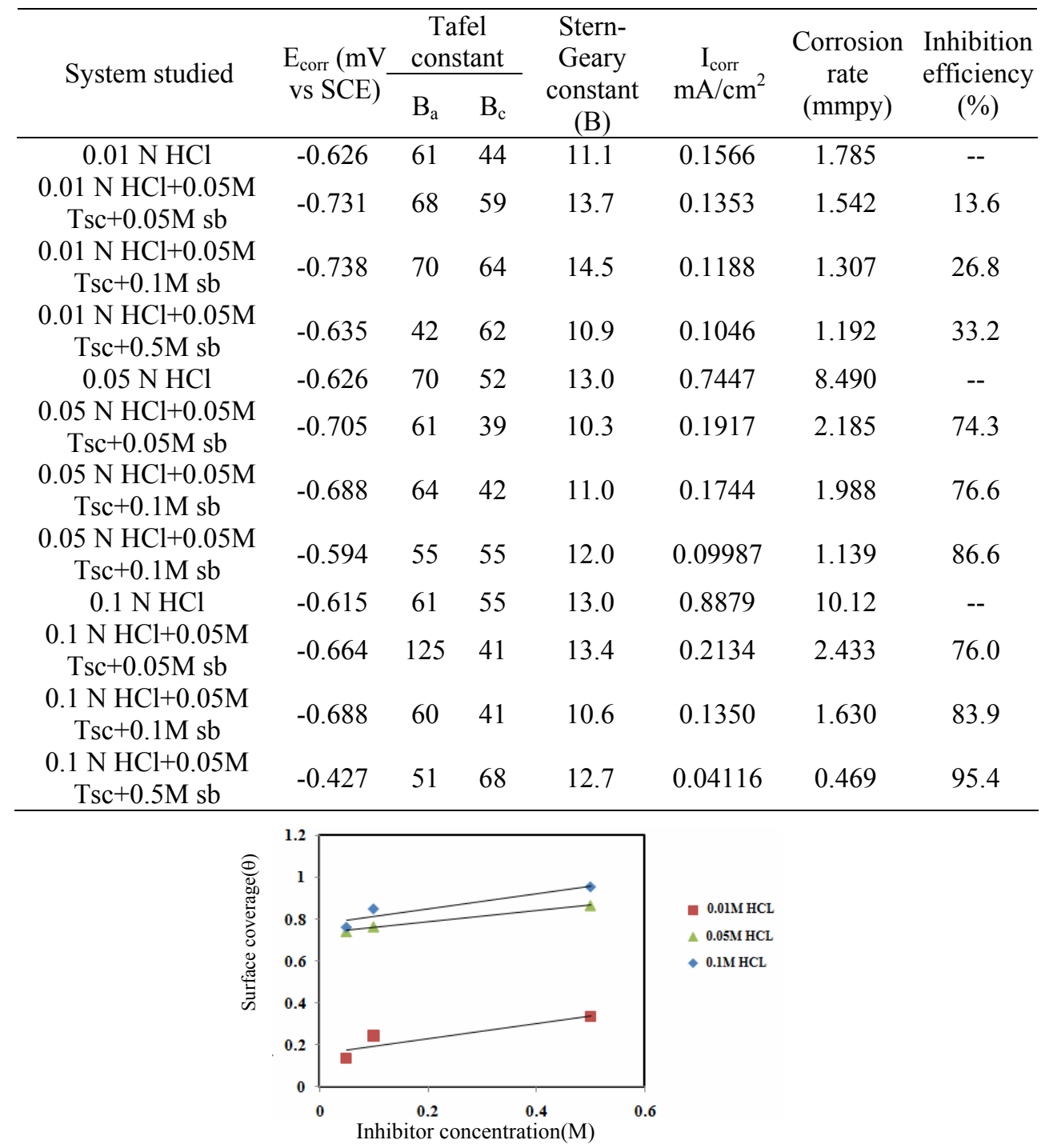

Figure 4. Temkin isotherm of citrate-benzoate inhibitors on the mild steel in $0.01,0.05$ and $0.1 \mathrm{~N} \mathrm{HCl}$ at $30^{\circ} \mathrm{C}$ 


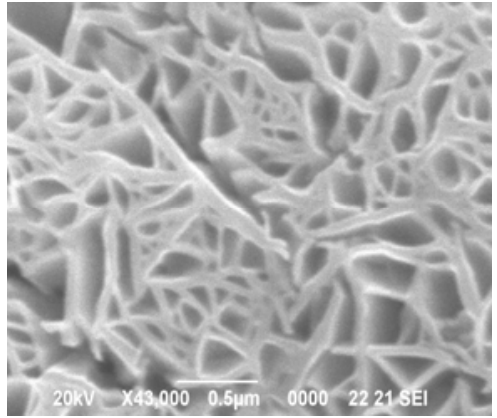

a

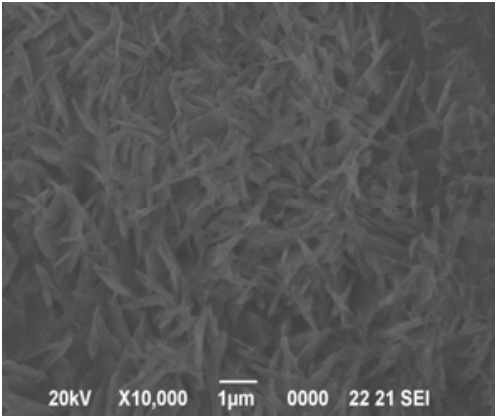

b

Figure 5. The SEM mild steel specimens: a) $0.1 \mathrm{~N} \mathrm{HCl}$ in the absence of inhibitors; b) $0.1 \mathrm{~N}$ $\mathrm{HCl}$ containing $0.05 \mathrm{M}$ Trisodium citrate and $0.5 \mathrm{M}$ sodium benzoate

\section{Impedance behaviour of mild steel in different concentration of $\mathrm{HCl}$}

The corrosion behaviour of mild steel in hydrochloric acid solution in the presence of different concentrations of mixed inhibitors such as, citrate and benzoate were investigated by EIS at room temperature. Figures 6-8 shows a typical set of Nyquist plots for mild steel in $0.01 \mathrm{~N} \mathrm{HCl}, 0.05 \mathrm{~N} \mathrm{HCl}$ and $0.1 \mathrm{~N} \mathrm{HCl}$ in the absence and presence of mixed inhibitors at various concentrations. The inhibition efficiency calculated from $R_{p}$ values were calculated using Stern-Geary equation and reported in Table 3. The impedance response of mild steel in uninhibited $\mathrm{HCl}$ is significantly changed after the addition of sodium benzoate to the trisodium citrate. The semicircle radii depend on the additive concentration. The diameter of the loop increased with increasing concentration of benzoate inhibitor, $\mathrm{Rp}$ is inversely proportional to the corrosion current and was used to calculate the inhibition efficiency from the following equations:

$$
\mathrm{I}_{\text {corr }}\left(\mathrm{mA} / \mathrm{cm}^{2}\right)=\mathrm{B} / \mathrm{R}_{\mathrm{p}} \text {, where } \mathrm{B} \text { is Stern-Geary constant. }
$$

$$
\text { I.E } \%=\frac{R_{u i}-R_{i}}{R_{u i}} \times 100
$$

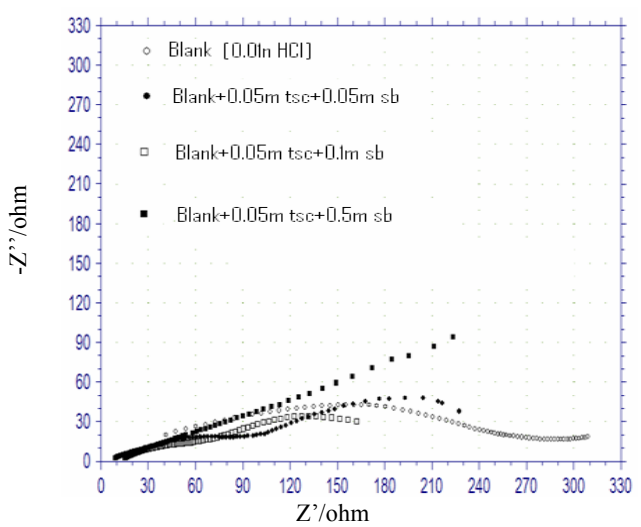

Figure 6. Nyquiste plot of mild steel in $0.01 \mathrm{~N} \mathrm{HCl}$ in absence and presence of various concentration of citrate and benzoate inhibitors

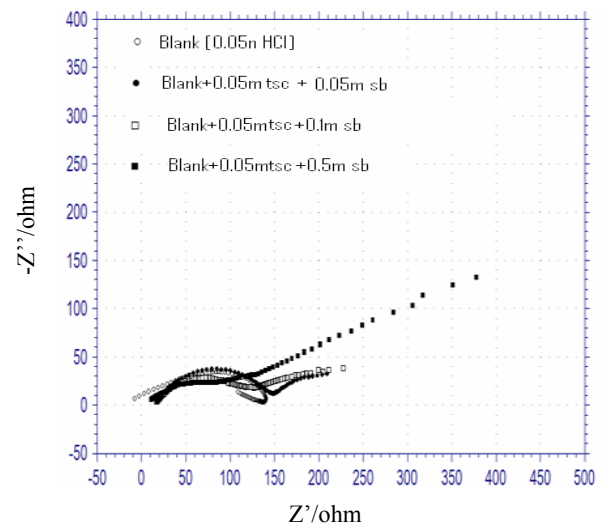

Figure 7. Nyquiste plot of mild steel in $0.05 \mathrm{~N} \mathrm{HCl}$ in absence and presence of various concentration of citrate and benzoate inhibitors 


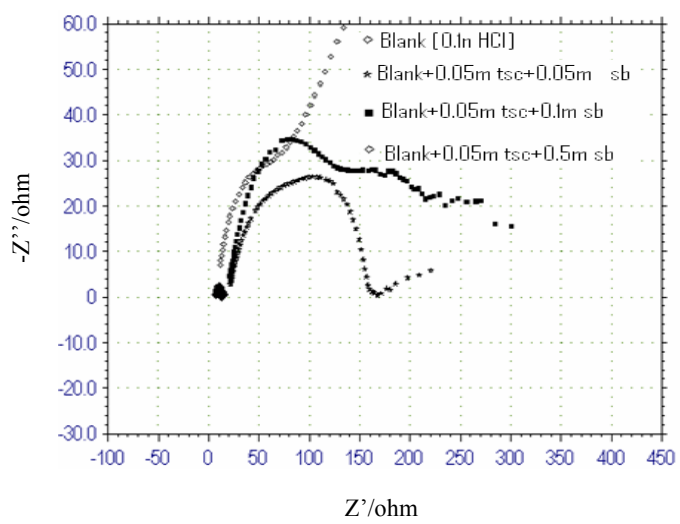

Figure 8. Nyquiste plot of mild steel in $0.1 \mathrm{~N} \mathrm{HCl}$ in absence and presence of various concentration of citrate and benzoate inhibitors

Table 3. Electrochemical impedance parameter for the corrosion of mild steel in different concentration of $\mathrm{HCl}$ and in different concentration of inhibitors

\begin{tabular}{|c|c|c|c|c|c|c|c|c|}
\hline System studied & $\mathrm{R}_{\mathrm{f}}$ & $\mathrm{R}_{\mathrm{ct}}$ & $\begin{array}{c}\text { Cdl } \\
\text { (film) } \\
\mu \mathrm{F} . \mathrm{cm}^{-2}\end{array}$ & $\begin{array}{c}\text { Cdl } \\
\text { (ct) } \\
\mu \mathrm{F} . \mathrm{cm}^{-2}\end{array}$ & 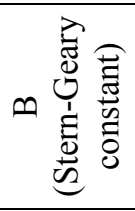 & $\begin{array}{c}\mathrm{I}_{\text {corr }} \\
\left(\mathrm{mA} / \mathrm{cm}^{2}\right)\end{array}$ & $\begin{array}{c}\text { Corrosion } \\
\text { Rate } \\
\text { (mmpy) }\end{array}$ & 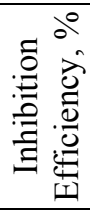 \\
\hline $0.01 \mathrm{~N} \mathrm{HCl}$ & -- & 180 & -- & 3.64 & 11.1 & 0.0617 & 0.7034 & -- \\
\hline $\begin{array}{c}0.01 \mathrm{~N} \mathrm{HCl}+0.05 \mathrm{M} \\
\text { Tsc }+0.05 \mathrm{M} \mathrm{sb}\end{array}$ & 52 & 190 & 34.87 & 6.80 & 13.7 & 0.0720 & 0.8208 & -- \\
\hline $\begin{array}{c}0.01 \mathrm{~N} \mathrm{HCl}+0.05 \mathrm{M} \\
\text { Tsc }+0.1 \mathrm{M} \mathrm{sb}\end{array}$ & 74 & 320 & 62.7 & 49.1 & 14.5 & 0.0453 & 0.5164 & 26.6 \\
\hline $\begin{array}{c}0.01 \mathrm{~N} \mathrm{HCl}+0.05 \mathrm{M} \\
\text { Tsc }+0.5 \mathrm{M} \mathrm{sb}\end{array}$ & 98 & 1300 & 5.7 & 4.53 & 10.9 & 0.0084 & 0.0958 & 86.4 \\
\hline $0.05 \mathrm{~N} \mathrm{HCl}$ & -- & 120 & -- & 4.7 & 13.0 & 0.1083 & 1.2346 & -- \\
\hline $\begin{array}{c}0.05 \mathrm{~N} \mathrm{HCl}+0.05 \mathrm{M} \\
\mathrm{Tsc}+0.05 \mathrm{M} \mathrm{sb}\end{array}$ & 40 & 600 & 77.6 & 10.9 & 10.3 & 0.0172 & 0.2030 & 83.6 \\
\hline $\begin{array}{c}0.05 \mathrm{~N} \mathrm{HCl}+0.05 \mathrm{M} \\
\mathrm{Tsc}+0.1 \mathrm{M} \mathrm{sb}\end{array}$ & 73 & 1100 & 23.4 & 19.1 & 11.0 & 0.0100 & 0.1140 & 90.8 \\
\hline $\begin{array}{c}0.05 \mathrm{~N} \mathrm{HCl}+0.05 \mathrm{M} \\
\mathrm{Tsc}+0.1 \mathrm{M} \mathrm{sb}\end{array}$ & 100 & 1700 & 1.2 & $\begin{array}{l}0.01 \mathrm{x} \\
10^{-3}\end{array}$ & 12.0 & 0.0071 & 0.0809 & 93.4 \\
\hline $0.1 \mathrm{~N} \mathrm{HCl}$ & -- & 6 & -- & 0.20 & 13.0 & 2.1667 & 24.700 & -- \\
\hline $\begin{array}{c}0.1 \mathrm{~N} \mathrm{HCl}+0.05 \mathrm{M} \\
\mathrm{Tsc}+0.05 \mathrm{M} \mathrm{sb}\end{array}$ & 84 & 130 & 33.6 & 33.6 & 13.4 & 0.1031 & 1.1753 & 95.2 \\
\hline $\begin{array}{c}0.1 \mathrm{~N} \mathrm{HCl}+0.05 \mathrm{M} \\
\text { Tsc }+0.1 \mathrm{M} \mathrm{sb}\end{array}$ & 104 & 250 & 13.0 & 13.0 & 10.6 & 0.0424 & 0.4834 & 98.0 \\
\hline $\begin{array}{c}0.1 \mathrm{~N} \mathrm{HCl}+0.05 \mathrm{M} \\
\mathrm{Tsc}+0.5 \mathrm{M} \mathrm{sb}\end{array}$ & 470 & 1850 & 4.80 & 4.80 & 12.7 & 0.0069 & 0.0787 & 99.7 \\
\hline
\end{tabular}

The maximum inhibition efficiency of $99.7 \%$ was obtained for the system $0.1 \mathrm{~N}$ $\mathrm{HCl}+0.05 \mathrm{M}$ Trisodium citrate $+0.5 \mathrm{M}$ Sodium benzoate and very low inhibition efficiency of 
$26.6 \%$ was obtained for the system $0.01 \mathrm{~N} \mathrm{HCl}+0.05 \mathrm{M}$ Trisodium citrate $+0.1 \mathrm{M}$ Sodium benzoate. These results clearly indicate that when both the acid and inhibitor concentration increases, the inhibition efficiencies also correspondingly increase.

\section{Conclusion}

The presence of sodium benzoate in trisodium citrate inhibitive mixed system reduced the corrosion rate of mild steel considerably in $\mathrm{HCl}$ medium. The Inhibition efficiency calculated from impedance and tafel polarization measurements were in good agreement. The benzoate containing in this mixed inhibitors influence the corrosion resistance performance significantly. The data revealed that the inhibition action of tested inhibitors was through adsorption type. The adsorption process obeyed the Tempkin adsorption isotherm. SEM images of mild steel specimens in the presence of inhibitors showed an almost smooth surface indicating the protective action of the inhibitor. From these observation it has been proven beyond doubt that the synergistic action of these mixed inhibitors shows an effective corrosion inhibitors for mitigating mild steel corrosion in $\mathrm{HCl}$ medium.

\section{References}

1. Ahmad Z, Principles of corrosion Engineering and corrosion control, ButterworthHeimemann, Ichem Eseries, Oxford (U.K), 2006, 367-369.

2. Umoren S.A, Ogbobe O, Igwe I.O and Ebenso E.E, Corros Sci., 2008, 50, 1998-2006.

3. Mirghasem H Sseini, Stijn F.L. Mertens, Hammed M and Arshadi, R, Corros Sci., 2003, 45, 1473-1489.

4. Quraishi M.A, Rana Sardar and Danish Jamal, Mat Chem Phy., 2001, 71, 309-313.

5. Divakara Shetty, S, Prakash Shetty and Sudhaker Nayak H V, Mat Lett., 2007, 61, 2347-2349.

6. Migahed M A, Azzam E M S and Al-Sabagh A.M, Mat Chem Phy.,2004, 85(2-3), 273-279.

7. Ramesh S and Rajeswari S, Electrochimica Acta, 2004, 49(5), 811-820.

8. Quraishi M.A, Rana Sardar and Danish Jama, Mat Chem Phy., 2001, 71, 309-313.

9. Vishnudevan M and Natesan, M, Bull Electrochem., 2000, 16, 49-53.

10. Elkadi L, Mernari B, Traisnel M, Bentiss F and Lagrene, M, Corros Sci., 2000, 42, 703-719.

11. Lebrini M, Bentiss, F, Vezin H and Lagrene'e M, Corros Sci., 2006, 48, 1279-1291.

12. Ali S A, El-Shareef A.M, Al-Ghamdi R.F and Saeed M.T, Corros Sci., 2005, 47(11), 2659-2678. 


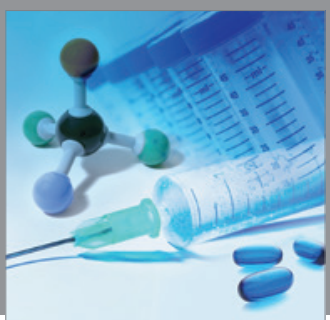

International Journal of

Medicinal Chemistry

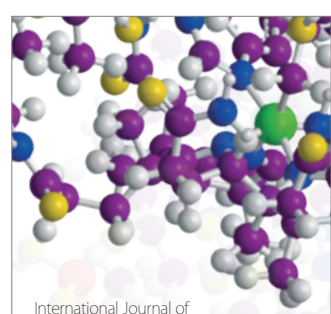

Carbohydrate Chemistry

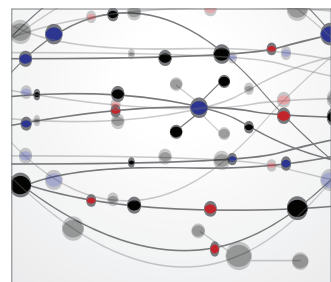

The Scientific World Journal
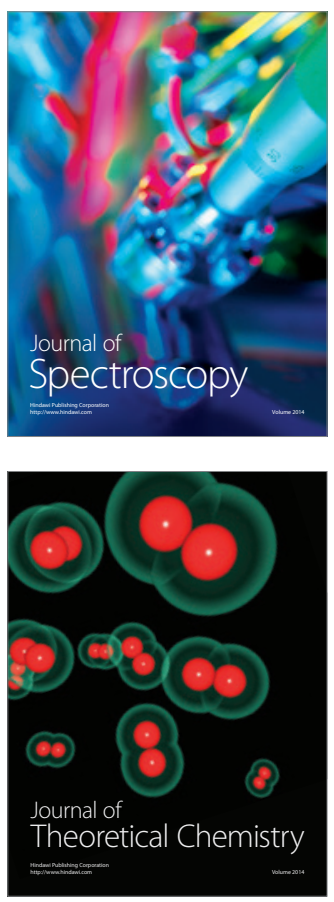
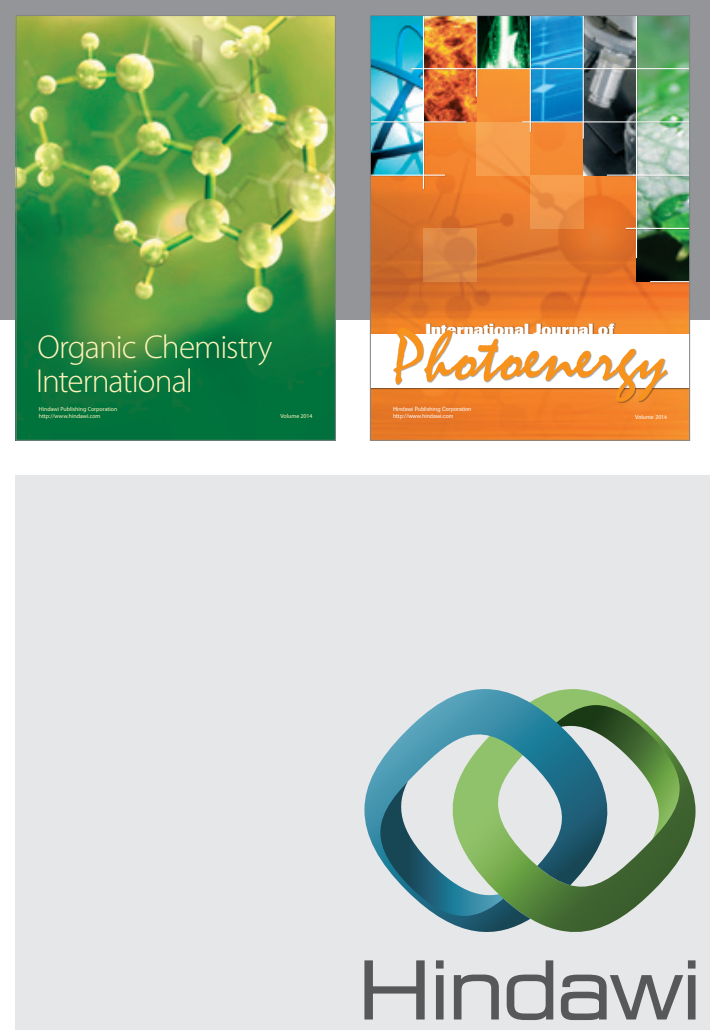

Submit your manuscripts at

http://www.hindawi.com
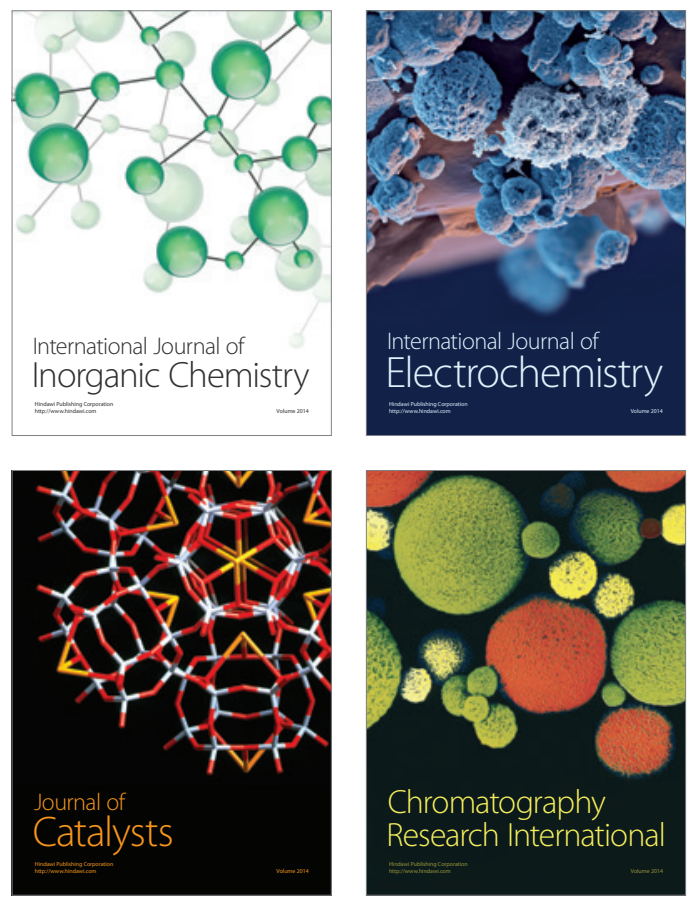
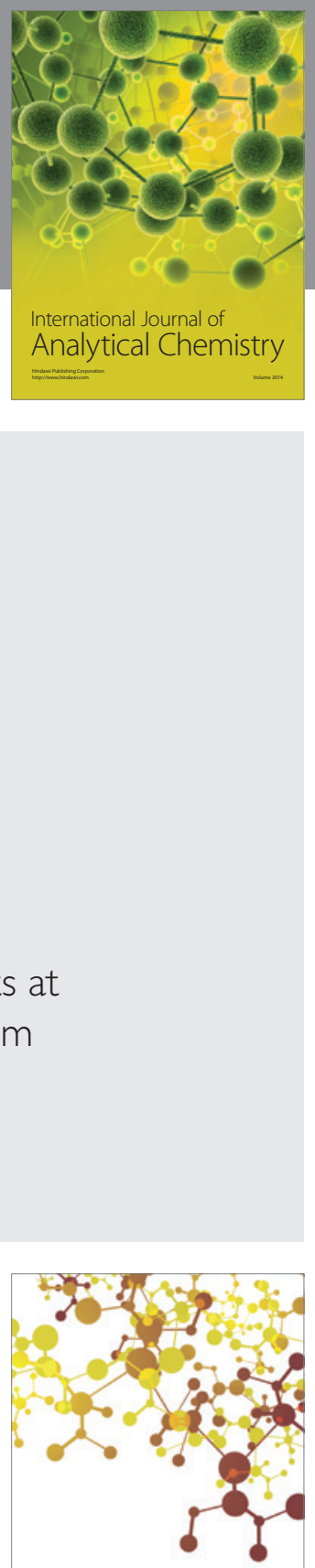

Journal of

Applied Chemistry
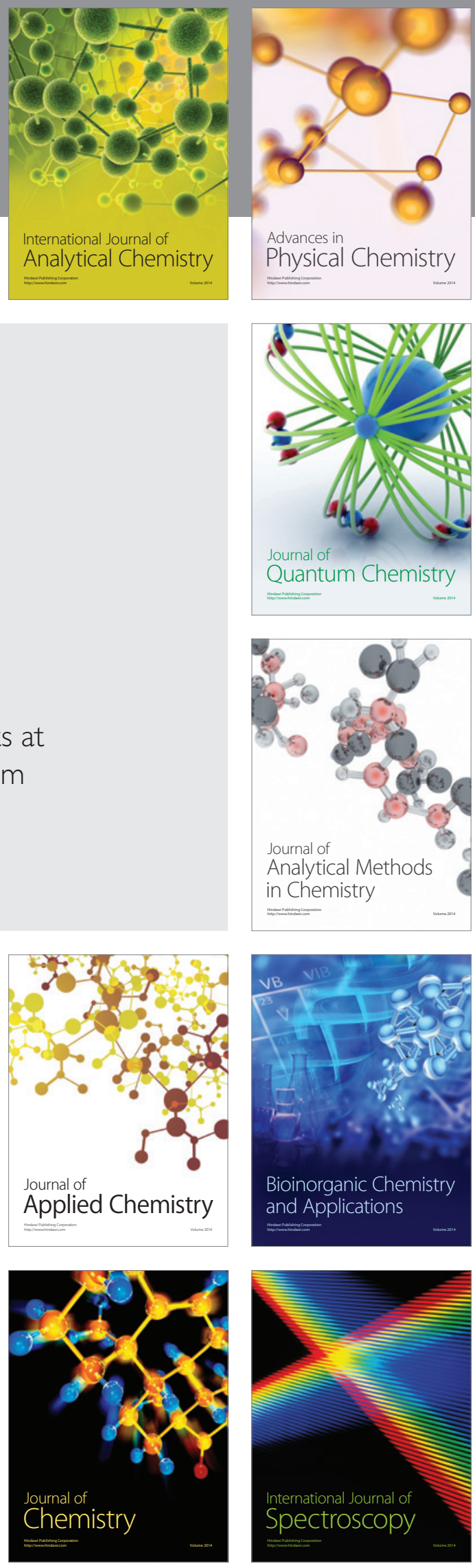